\title{
Soybean Sprouts: A Review of Nutrient Composition, Health Benefits and Genetic Variation
}

\author{
Mirwais Ghani ${ }^{1,3}$, Krishnanand P. Kulkami ${ }^{1}$, Jong Tae Song ${ }^{1}$, J. Grover Shannon ${ }^{2}$, Jeong-Dong Lee ${ }^{1 *}$ \\ ${ }^{1}$ School of Applied Biosciences, Kyungpook National University, Daegu 41566, Korea \\ ${ }^{2}$ Division of Plant Sciences, University of Missouri-Delta Center, Portageville, MO 63873, USA \\ ${ }^{3}$ Nutrition \& Education International (NEI) Organization, Wakil Samad Alley, Dehburi 1006, Kabul, Afghanistan
}

\begin{abstract}
Soybean [Glycine max (L.) Merr.] sprouts are highly digestible and a year around vegetable suitable for human consumption. Sprouting process causes a number of biochemical changes inside the seed, resulting in the accumulation of various primary and secondary metabolites. Due to such changes, sprouts contain high levels of health-promoting phytochemicals as compared to other vegetables. Sprouts are an excellent source of protein, amino acids, and vitamins, which provide numerous health benefits. Due to such advantages, soybean sprouts have been preferred as a part of daily diets in Korea and quality soybean sprouts are in high demand in the edible food market. To produce high quality soybean sprouts, several factors, including the choice of the variety, health benefits from sprout phytonutrients and inherent genetic variation for the sprout-related traits of the variety need to be considered. In this review, we have summarized literature on soybean sprout components, the health benefits, changes in nutritional factors during the sprouting process and the genetic variation among the cultivars developed for sprout usage. We have also reviewed procedures and factors like seed characteristics, temperature, chemical applications that influence the sprouting process. The information collectively presented here will be useful for understanding the progress of soybean cultivars developed for soybean sprout development and use.
\end{abstract}

Keywords Soybean, Sporut

\section{INTRODUCTION}

Sprouting, the germination stage of a seed, is a growing market for use of soybeans as an edible and nutritious vegetable. Crops like soybean [Glycine max (L.) Merr.], mungbean (Vigna radiata), alfalfa (Medicago sativa) are highly suitable for sprout production and human consumption (Silva et al. 2013). Sprouts can be prepared within 5-7 days from initial germination and can be available as a vegetable throughout the year (Silva et al. 2013). During the initial stages of germination, several biochemical changes occur inside the seed. For instance, macro-molecules such as proteins, polysaccharides and fats may break down into oligopeptides and free amino acids, monosaccharides and oligosaccharides, and fatty acids, respectively (Bau et al. 1997). This process initiates the accumulation of several primary metabolites and increases the overall content of available nutrients, thereby improving the nutritive value of the sprouts.

Sprouts have several health benefits: 1) the sprouting process reduces the content of several unfavorable and anti-nutritional components like trypsin inhibitor and phytic acid related to problems in digestion (Doblado et al. 2007), 2) sprouts contain an increased amount of some of the bioactive compounds which have a role in protecting cells against damage caused by free radicals (Hochstein and Atallah 1988), 3) sprouting produces enzymes that aid in digestion, and 4) sprouting frees amino acids, fatty acids,

Received August 19, 2016; Revised October 30, 2016; Accepted October 30, 2016; Published November 30, 2016

*Corresponding author Jeong-Dong Lee, jdlee@knu.ac.kr, Tel: +82-53-950-5709, Fax: +82-53-958-6880 
vitamins and minerals that otherwise would not be available for human nutrition.

Soybean sprouts (Kongnamul in Korea) have been preferred as a part of the daily diet in Korea, Japan and China over the years. The exact origin of kongnamul is unknown, but it is assumed that it has been eaten since the period of Three Kingdoms of Korea (B.C. 1-935) or the early Goryeo era (918-1392). Records of kongnamul can be found in the documents from the Goryeo era, Hyangyak Gugeupbang where cultivation of sprouts are mentioned. Taejo, the first King of Goryeo, and his soldiers were saved from starvation by growing bean sprouts in nearby streams. In the Joseon era (1392-1897) the document Sallim gyeongie, briefly refer to sprout cooking methods and in another Joseon era document Seonghosaseol it is stated that the poor used kongnamul to make juk. Kongnamul is again mentioned in Cheongjanggwanjeonseo as the main food consumed during famines (https://en.wikipedia.org/wiki/Kongnamul).

There is increased demand for soybean varieties that efficiently produce high quality sprouts. Cataloguing information of the nutrient composition and health benefits of sprouts and genetic variation for sprout-related traits in soybean cultivars developed for sprout purposes would be highly useful for breeders and farmers. In this review, we conducted a comprehensive assessment of changes in nutritional factors during the sprouting process and their benefits for human health, factors affecting the sprouting process and the available genetic variation among the cultivars developed for soybean sprout production.

\section{SOYBEAN AND SOYBEAN SPROUTS}

Soybeans are an important part of the typical Korean diet due to the protein, oil and other components (Liu 1999). Soybean seed contains an average of $40 \%$ protein and $20 \%$ oil on a dry weight basis. The remaining $40 \%$ of the seed is comprised of carbohydrates, vitamins, phytochemicals, minerals and other minor elements. Different recipes like soymilk, soy sprouts, vegetable soybean and soy paste, served with rice are preferred among many oriental people. Among them, sprouts have been a common vegetable for centuries, particularly in areas where seasonal vegetables were not available during the winter season (Shi et al. 2010; Yang et al. 2015). Soybean sprouts have been used in different recipes like soy sauce, mixing with rice, in soup and as a fresh salad. This diversity of consumption of soybean sprouts has increased demand of soybean varieties that produce high quality sprouts. Thick hypocotyls, high germination percentage, rapid water absorption, small seed size, and high yield are important factors in soybean sprout production (Kim et al. 1994; Park et al. 1994). Soybean sprouts have high nutritional value and are relatively easy to produce, making them a desirable vegetable (Lee et al. 2007a).

\section{HEALTH BENEFITS AND NUTRITIONAL COMPOSITION OF THE SOYBEAN SPROUTS}

Soybean sprouts contain nutritional components including isoflavones (Phommalth et al. 2008), riboflavin and niacin (Kylen and McCready 1975) along with crude protein, amino acids and lipids (Mostafa and Rahma 1987). They also contain high amounts of macro- and micro-elements such as sodium, zinc, copper, potassium, iron, phosphorus, magnesium and manganese. These constituents are distributed in the hypocotyls and cotyledons in varied amounts depending on the soybean variety (Plaza et al. 2003; Youn et al. 2011). Consumption of soybean sprouts provide numerous health benefits like reducing the risk of cardiovascular diseases and cancer, due to the presence of several health-promoting phytochemicals with high antioxidant properties (Prakash et al. 2007). In addition, anti-nutritional factors like hemagglutinin, trypsin inhibitors, and lipoxygenase decrease during sprouting (Shi et al. 2010). Most of these compounds benefit human health and are discussed in details below.

\section{Amino acid and protein content}

Amino acids and proteins are the building blocks of life. Every cell in humans uses amino acids to synthesize proteins, which are essential to perform different functions like transport and storage of nutrients and development of cell structure, etc. (Zaman et al. 2010). Crude protein levels 
of up to $46 \%$ have been reported in soybean sprouts (Bau $e t$ al. 1997), but levels vary during sprouting. Lee and Chung (1982) reported an increase in the crude protein content, whereas Choi et al. (2000b) reported a decrease in the crude protein levels after 5 days of sprouting.

Soybean sprouts contain high amounts of essential and non-essential amino acids (Oh et al. 2004; Suh et al. 2004; Oh et al. 2005; Park et al. 2005; Yun et al. 2005; Oh et al. 2006a; Oh et al. 2006b; Oh et al. 2007a; Oh et al. 2007b; Oh et al. 2007c; Oh et al. 2008; Phommalth et al. 2008; Cho et al. 2009; Oh et al. 2009a; Oh et al. 2009b; Kim et al. 2013) (Table 1). The concentration of the total amino acids varies across different soybean genotypes (Table 1) and during the days of sprouting (Song et al. 2000). For instance, sprouts from the variety Bosug contained higher amounts of amino acids than other cultivars. Another cultivar, Pungsannamulkong (Pungsannamul) (Suh et al. 1996) was found to contain $348 \mathrm{mg}$ amino acids per gram of sprout (Oh et al. 2005). The cultivars Dagi and Sunam contained relatively lesser amounts of amino acids (Table 1). Free amino acid content was also found to vary during the sprouting process. Generally, most of the free amino acids increased during sprouting (Yang 1981). Soybean seeds collected from Japan, United States and China were reported to have $437.2 \mathrm{mg}, 452.2 \mathrm{mg}$ and $367.2 \mathrm{mg} / 100 \mathrm{~g}$ of free amino acids and increased up to $12,768.8 \mathrm{mg}, 10,845.9$ $\mathrm{mg}$, and $11,931 \mathrm{mg} / 100 \mathrm{~g}$ dry weight, respectively during the sprouting process (Mizuno and Yamada 2006). Particularly, the asparagine increased dramatically (Byun et al. 1977; Lee and Hwang 1996). Asparagine contents were $25 \%$ of dry weight after 15 days sprouting (Byun et al. 1977), and it increased from $42.9 \mathrm{mg} / 100 \mathrm{~g}$ in the seed to $7,423.3 \mathrm{mg} / 100 \mathrm{~g}$ in the sprout. The content of asparagine and aspartic acid varied among the different soybean varieties and showed positive correlation with sprouting days (Lee and Hwang 1996). Soybean sprout soup is one of best hangover foods in Korea because of its asparagine content, which is known to have detoxifying effects on acetaldehyde, a highly toxic metabolite produced in alcohol metabolism in humans (Lee and Hwang 1996). Significant increases have been observed in the concentrations of glutamate, histidine, alanine, proline, lysine, valine and isoleucine during sprouting (Friedman and Brandon 2001; Villaluenga et al. 2006). These reports show substantial variation for the amino acid content and composition, especially for the essential amino acids.

Table 1. Amino acid and isoflavone content in soybean sprouts in 17 soybean cultivars.

\begin{tabular}{|c|c|c|c|c|c|c|c|}
\hline \multirow{2}{*}{ Cultivar } & \multicolumn{2}{|c|}{ Amino acid $(\mathrm{mg} / \mathrm{g})$} & \multicolumn{4}{|c|}{ Isoflavone content $(\mu \mathrm{g} / \mathrm{g})$} & \multirow{2}{*}{ Reference } \\
\hline & Total & Essential & Daidzein & Glycitein & Genestein & Total & \\
\hline Aga3 & - & - & - & - & - & 10,788 & Phommalth et al. 2008 \\
\hline Anpyeong & 44.5 & - & - & - & - & 2,679 & Yun et al. 2005 \\
\hline Bosug & 396 & 174 & 1,422 & 382 & 2,087 & 3,891 & Oh et al. 2005 \\
\hline Dagi & 42.8 & - & 1,073 & 774 & 1,722 & 3,569 & Oh et al. 2004 \\
\hline Galchae & - & - & 460 & 970 & 670 & 2,120 & Oh et al. 2009a \\
\hline Hoseo & 133 & 56 & 1,160 & - & 1,240 & 2,600 & Oh et al. 2008 \\
\hline Jangki & 238 & 83 & 2,092 & 733 & 2,412 & 5,237 & Oh et al. 2006a \\
\hline Jonam & 82 & 14 & 1,135 & - & 1,832 & 3,574 & Oh et al. $2007 \mathrm{a}$ \\
\hline Pungwon & 169 & 69 & 2,587 & 2,959 & - & 5,935 & $\mathrm{Oh}$ et al. 2007c \\
\hline Sohwang & - & - & 816 & 1,099 & 1,126 & 3,041 & Cho et al. 2009 \\
\hline Sojin & 46.6 & - & - & - & - & 3,765 & Park et al. 2005 \\
\hline Sokang & 295 & 127 & 1,612 & 777 & 2,129 & 4,518 & $\mathrm{Oh}$ et al. 2006b \\
\hline Sunam & 43.5 & - & 391 & 93 & 1,160 & 1,644 & Suh et al. 2004 \\
\hline Tawonkong & - & 21 & - & - & - & 713 & Kim et al. 2013 \\
\hline Wonheug & - & 19 & - & - & - & 1,309 & Kim et al. 2013 \\
\hline Wonhwang & 174 & 63 & 2,052 & 764 & 2,554 & 5,370 & $\mathrm{Oh}$ et al. $2007 \mathrm{~b}$ \\
\hline Wonkwang & 104 & 46 & 1,493 & - & 1,685 & 3,481 & Oh et al. 2009b \\
\hline
\end{tabular}




\section{Oil and fatty acid content}

Soybean oil is one of the most preferred vegetable oils used for food and other applications. Oil content ranges from $8.3 \%$ to $27.9 \%$, with an average of $18.1 \%$ on a $13 \%$ moisture basis in soybean seed (Liu 1999; Wilson 2004). Soybean oil is a fat, and a soluble vitamin transporter throughout the body and helps adjust body temperature (Karasulu et al. 2011). Oil content decreased (Kim 1981) from $15 \%$ to $10 \%$ during sprouting (Shi et al. 2010). The quality of soybean oil is primarily associated with its fatty acid composition. Slight changes in fatty acid levels of sprouts have been reported. Mizuno and Yamada (2006) observed slight increases in palmitic acid, stearic acid and oleic acid contents but decreases in linoleic acid (LA) and $\alpha$-linolenic acid (ALA) contents during sprouting. Lee et al. (2002) reported increase in the LA content, but a decrease in the ALA content in 5-day-old sprouts. Contrary to this, the ALA content increased (Dhakal et al. 2009) or did not change during sprouting (Dhakal et al. 2014). Similar results were found in sprouts of the soybean variety, Calland after 5 days of sprouting (Mostafa and Rahma 1987). Therefore, fatty acid composition of soybean sprouts depends not only on the cultivar, but also on other factors like the days of sprouting (Dhakal et al. 2009) and growth environment (Yang et al. 1982).

\section{Isoflavone content}

Isoflavones are a class of phytoestrogens, the plantderived compounds that possess a wide range of biological activities (Shi et al. 2010). Although many plants are reported to contain isoflavones, four plants namely soybean, chickpea, onion and apple have been reported as the major sources of isoflavones (Dixon and Sumner 2003). Consumption of isoflavones provide various health benefits such as decreasing risks of cardiovascular disease, menopausal symptoms, protection from cancers, and bone resorption (Messina 2000; Allred et al. 2004; Prakash et al. 2007). Due to these advantages, selection for high isoflavones content in soybean seeds has been a goal of soybean breeders in recent years.

Total isoflavone content in soybean seed range from $0.05 \%$ to $0.5 \%$ of the dry weight (Lee et al. 2004). Several studies have been conducted to reveal the type and quantities of isoflavones in soybean seed and sprouts (Messina et al. 1994; Anderson and Ganer 1997; Kim et al. 2003; Kim et al. 2006). Generally, the isoflavone content in soybean sprouts is higher than in the seed (Kim et al. 2003; Kim et al. 2004; Kim et al. 2006). Distribution of isoflavone content varies in roots, cotyledons and hypocotyls of soybean plants (Kim et al. 2003; Kim et al. 2006). High quantities of isoflavones have been observed in roots and hypocotyls compared to the other sprout components (Lee et al. 2007c). Large phenotypic variation for isoflavone content has been observed in soybean sprout genotypes (Table 1). For instance, 7-day-old sprouts produced from the cultivar Aga3 contained isoflavone concentration of $10,788 \mu \mathrm{g} / \mathrm{g}$, compared to $3,556 \mu \mathrm{g} / \mathrm{g}$ contained in the sprouts from Pungsannamul, the most favored sprout cultivar in Korea (Phommalth et al. 2008). The cultivars, Pungwon (Oh et al. 2007c) and Wonhwang (Oh et al. 2007b) had isoflavone contents of $5,935 \mu \mathrm{g} / \mathrm{g}$ and $5,370 \mu \mathrm{g} / \mathrm{g}$, respectively. Similarly, the cultivar Tawonkong (Kim et al. 1996) was reported to have low sprout isoflavone content (Kim et al. 2013). Isoflavone content in soybean seed and sprouts not only depends on the soybean cultivar, but it is also affected by the year of seed production, temperature, light and soybean field conditions (Hoeck et al. 2000; Xu et al. 2003; Seguin et al. 2004; Zhu et al. 2005). For instance, light caused an increase in the isoflavone content during sprouting (Chi et al. 2005).

\section{Vitamin content}

Vitamins are essential organic compounds having a high impact on human health. They are essential for plant and animal metabolism due to their role as enzymatic cofactors (Asensi-Fabado and Munné-Bosch 2010). Vitamin deficiencies may cause disorders which can be severe and even lethal in some cases. An adequate supply of vitamins can thus prevent such diseases and disorders (Kraemer et al. 2008). Since humans cannot synthesize vitamins, they must be acquired from their diets (Miret and Munné-Bosch 2014).

Soybean seeds are known to contain vitamin A, B1, E, and C (Collin and Sanders 1976). Many experiments have revealed that sprouting significantly improves content of 
these vitamins (Plaza et al. 2003; Youn et al. 2011). For instance, Collins and Sanders (1976) reported that vitamin B1 content in soybean sprouts was 2-times higher than in the raw seeds. Also, vitamin $\mathrm{C}$ content increased 4 to 20 times during 4-5 days of germination (Plaza et al. 2003) (Table 2). Higher levels of vitamin $\mathrm{C}$ were observed in hypocotyls than in the cotyledons (Youn et al. 2011). Normally, the soybean seeds contains an average of 2 $\mathrm{mg} / 100 \mathrm{~g}$ of vitamin $\mathrm{C}$, but increased up to $11 \mathrm{mg} / 100 \mathrm{~g}$ after 5 days of sprouting (Liu 1999). Similarly, soybean seeds contained about $0.12 \mathrm{mg} \beta$-carotene $/ 100 \mathrm{~g}$, whereas 5 -day-old sprouts contained about $0.2 \mathrm{mg} / 100 \mathrm{~g}$ (Liu 1999). Lee et al. (2013) reported an increase in the levels of the vitamins, lutein and $\beta$-carotene in whole sprouts of soybean varieties Pungsannamul and Bosug. They observed about a 20,24 fold increase in the lutein levels and an 8,17 fold increase in the $\beta$-carotene level, in Pungsannamul and Bosug, respectively. The average $\beta$-carotene content in soybean seed was $6.6 \mu \mathrm{g} / \mathrm{g}$ whereas, in the 5-day-old sprouts, it was $33.3 \mu \mathrm{g} / \mathrm{g}$ (Kang et al. 2012).

\section{Saponin content}

Saponins (glycosides) are the secondary plant metabolites, found in several pants and plant-derived foods
(Price et al. 1986). They provide several health benefits such as decreasing blood cholesterol levels (Lee et al. 2005), lowering blood glucose (Tanaka et al. 2006) and protecting against kidney diseases (Philbrick et al. 2003). Saponin content in soybean seed constitute about $0.5 \%$ of total dry weight (Fenwick and Oakenfull 1983) and range from $0.6 \%$ to $6.5 \%$ of dry weight (Tsukamoto et al. 1995). Oh et al. (2003) reported that crude saponin content in the cultivar Eunhakong (Shin et al. 1988) increased from 4.59 $\mathrm{mg} / \mathrm{g}$ in the seeds to $5.33 \mathrm{mg} / \mathrm{g}$ in 6-day-old sprouts. Saponin content was highest in hypocotyls as compared to cotyledons and roots (Shimoyamada et al. 1990; Shimoyamada and Okubo 1991; Oh et al. 2003). Increases in levels of different kinds of saponins, like saponin group B (Oh et al. 2003; Jang and Han 2016), total soyasapogenol and soyasapogenol B (Kang et al. 2010) have been observed. Similarly, a decrease in the content of soyasapogenol A among 79 Korean cultivars was also observed (Kang et al. 2010). Such alterations in the saponin content seems to be highly influenced by the growing environments and may be determined by several factors like the type of cultivar, seed size, year of production, location grown and maturity (Rupasinghe et al. 2003). For instance, Yoshiki et al. (1998) reported increases in the saponin levels when the sprouting process was carried out in lighted

Table 2. Differences in the vitamin and mineral content in soybean seed and sprouts (Plaza et al. 2003).

\begin{tabular}{|c|c|c|c|}
\hline Component & & Dry seed & Sprouts ${ }^{\mathrm{z}}$ \\
\hline \multirow[t]{6}{*}{ Vitamins } & Vitamin A (RE per 100 g d.w $)^{\mathrm{y})}$ & 18.79 & 34.02 \\
\hline & Vitamin E ( $\alpha$-tocopherol $\mu \mathrm{g} / \mathrm{g}$ d.w $)$ & 0.89 & 5.91 \\
\hline & Vitamin B1 (thiamine $\mu \mathrm{g} / \mathrm{g}$ d.w) & 0.47 & 2.01 \\
\hline & Vitamin B2 (riboflavin $\mu \mathrm{g} / \mathrm{g}$ d.w) & 1.29 & 14.8 \\
\hline & Vitamin B6 (pyridoxal $\mu \mathrm{g} / \mathrm{g}$ d.w) & 7.79 & 19.08 \\
\hline & Vitamin $\mathrm{C}$ (ascorbic acid $\mu \mathrm{g} / \mathrm{g}$ d.w) & 99.51 & 316.44 \\
\hline \multirow[t]{8}{*}{ Minerals } & Zn $(\mu \mathrm{g} / \mathrm{g}$ d.w $)$ & 23.93 & 85.88 \\
\hline & $\mathrm{Ca}(\mu \mathrm{g} / \mathrm{g}$ d.w) & 810 & 2,770 \\
\hline & $\mathrm{Na}(\mu \mathrm{g} / \mathrm{g}$ d.w $)$ & 2,610 & 8,600 \\
\hline & $\operatorname{Mn}(\mu \mathrm{g} / \mathrm{g}$ d.w $)$ & 6.72 & 19.61 \\
\hline & $\mathrm{K}(\mu \mathrm{g} / \mathrm{g}$ d.w $)$ & 2,070 & 10,170 \\
\hline & $\mathrm{Cu}(\mu \mathrm{g} / \mathrm{g}$ d.w $)$ & 11.43 & 19.61 \\
\hline & $\operatorname{Mg}(\mu \mathrm{g} / \mathrm{g}$ d.w $)$ & 1,330 & 1510 \\
\hline & $\mathrm{Fe}(\mu \mathrm{g} / \mathrm{g}$ d.w $)$ & 48.87 & 35.29 \\
\hline
\end{tabular}

\footnotetext{
${ }^{\text {z) }}$ Sprouts cultured for four days.

${ }^{\mathrm{y})}$ Vitamin A content is calculated as retinol equivalents ( $\mathrm{RE}=\mu \mathrm{g} \beta$-carotene/6) per $100 \mathrm{~g}$ on dry weight (d.w) basis of seeds and sprouts.
} 
conditions.

\section{Sugar content}

Soybean seed contains approximately 33\% carbohydrates, up to $16.6 \%$ of which are soluble sugars (Hymowit and Collins 1974). The soluble sugar fraction is mainly comprised sucrose, raffinose and stachoyse (Yazdi-Samadi et al. 1977; Eldridge et al. 1979), which range from $41.3 \%$ to $67.5 \%, 5.2 \%$ to $15.8 \%$ and $12.1 \%$ to $35.2 \%$, respectively (Yazdi-Samadi et al. 1977). Seed also contain glucose and fructose, whose concentration is $<1 \%$ (Hymowitz and Collins 1974). Glucose, fructose and sucrose are considered desirable sugars due to the sweet taste and ease of digestion, but stachyose and raffinose are undesirable sugars, indigestible and cause flatulence and diarrhea (Wang et al. 2014). The sugar content in soybean seed is not stable across environments and wide variation has been observed among genotypes (Hartwig et al. 1997). The sugar content in soybean seed decreased during the sprouting process. Shi et al. (2010) found that sugar content in soybean seed was $19.9 \%$ but decreased to $14 \%$ after 7 days of sprouting. Similarly, Silva et al. (1990) reported more than $90 \%$ decreases in the stachyose and raffinose content in Brazilian soybean cultivar after four days of germination.

\section{Mineral content}

Soybean sprouts contain different minerals like $\mathrm{Zn}, \mathrm{Na}$, $\mathrm{Fe}, \mathrm{Ca}$, and others which are important for human nutrition. In sprouts, these minerals are largely distributed between hypocotyls and cotyledons in variable amounts (Youn et al. 2011). Differences in the soybean mineral concentrations between dry seed and sprouts are shown in Table 2 . Contents of $\mathrm{Zn}, \mathrm{Ca}, \mathrm{Na}, \mathrm{Mn}, \mathrm{K}$, and $\mathrm{Cu}$ increased significantly whereas Fe decreased during sprouting. Fe content in raw seed was 48.87 ( $\mu \mathrm{g} / \mathrm{g}$ dry weight) whereas in 4-day-old sprouts, it was 35.29 ( $\mu \mathrm{g} / \mathrm{g}$ dry weight) (Plaza et al. 2003). However, since the presence of minerals in soybean sprouts depend on soybean cultivar and sprouting conditions, slight variations may be observed (Bau et al. 1997).

\section{FACTORS IMPORTANT FOR THE YIELD AND QUALITY OF THE SOYBEAN SPROUTS}

Since the sprouting procedure is not unique and different approaches are used as a matter of convenience, numerous factors are known to affect the sprouting process. Generally, soybean sprouts are prepared as follows: well cleaned seeds are soaked in water to incubate for several hours at room temperature, and then placed in an appropriate vessel having small holes at the bottom for draining water. The vessels are kept in a dark place and watered several times a day. After 4-5 days, seedlings are washed thoroughly and de-hulled (Liu 1999; Lee et al. 2007a). During the sprouting process, many factors that affect growth and quality of the seedlings must be understood to produce sprouts with high quality and high yield. Some of the important factors are discussed below.

\section{Seed size and quality}

Seed size is one of the factors considered essential while choosing a soybean cultivar for sprout production. Small to medium-sized seeds are routinely preferred for sprouting because they usually have better and uniform germination. In addition, small seeded soybeans are known to produce sprouts with good taste and high yield (Liu 1999; Kim et al. 2000; Kim et al. 2004; Lee et al. 2007a). Soybeans having seed weight $<120 \mathrm{mg} / \mathrm{seed}$ are usually preferred for sprout production (Kwon et al. 1972). Soybeans having small seed size are known to have better water absorption, longer hypocotyls lengths, and a high germination percentage (Kim et al. 1994; Park et al. 1994). In addition to seed-size, other factors like seed coat color, purity and removal of broken/damaged or diseased seeds also affect sprout quality and length.

\section{Light}

Light can have negative effects on soybean sprout quality during germination. Light affects root elongation and initiates photosynthesis, turning the cotyledons a green color. Both, long roots and green cotyledons, are undesirable for soybean sprouts (Liu 1999; Shi et al. 2010). Generally, sprouts having shorter roots, white hypocotyls 
of about 8-12 cm length and bright yellow cotyledons are greatly preferred by consumers and have high market value (Park et al. 1995; Lee et al. 2007a). Thus, performing the complete sprouting process in darkness, is crucial for minimizing undesirable sprouts.

\section{Temperature and humidity}

Air, water temperature and humidity have a profound effect on soybean germination, sprout quality and yield. Low temperatures cause negative effects on time of initial germination until sprout harvest, hypocotyl length, thickness and sprout quality (Tajiri 1980). A water temperature of more than $20^{\circ} \mathrm{C}$ is generally preferred during seed imbibition (Tajiri 1980; Lee et al. 2007a). Air temperature within the range of $20^{\circ} \mathrm{C}$ to $23^{\circ} \mathrm{C}$ during the incubation period (sprouting time) is recommended for good quality sprout production. Sprinkling sprouts with water after initiating germination is essential in reducing the temperature, removing the organic matter and providing oxygen inside sprout culture equipment. Therefore, water should be applied several times during sprouting (Park and Kim 1998). In addition, when the temperature of the water used for sprinkling is higher than $21^{\circ} \mathrm{C}$, it may have some positive effects on hypocotyl length and diameter (Beeskow 1944). Koo et al. (2015) observed sprout whole lengths and hypocotyl lengths that were twice as long and higher in yield cultured at $25^{\circ} \mathrm{C}$, as compared to those cultured at $20^{\circ} \mathrm{C}$. The hypocotyl thickness was similar in the sprouts cultured at both the temperatures. Relative humidity of $80 \%$ is generally recommended to have an environment conducive to low seedling disease and uniform germination (Lee et al. 2007a).

\section{Hypocotyls in soybean sprouts}

The hypocotyl is a main part of sprouts along with cotyledons. The desirable hypocotyl length generally is in the range of $8-12 \mathrm{~cm}$ and hypocotyl thickness in the range of 2.0-2.2 $\mathrm{mm}$ at sprout harvest 5 days of sprouting, (Lee $\mathrm{et}$ al. 2007a). Many of soybean varieties developed for sprout purposes, have been reported to exhibit high phenotypic variation for the sprout characteristics like hypocotyl length and thickness. Characteristics of such cultivars developed for sprout usage since the year 2000 are listed in the Table 3 (Baek 2001; Shin et al. 2002; Shin et al. 2003; Oh et al. 2004; Suh et al. 2004; Kim et al. 2005; Oh et al. 2005; Park et al. 2005; Yun et al. 2005; Oh et al. 2006a; Oh et al. 2006b; Oh et al. 2007a; Oh et al. 2007b; Oh et al. 2007c; Oh et al. 2008; Cho et al. 2009; Lee et al. 2009; Oh et al. 2009a; Oh et al. 2009b; Kim et al. 2013; Kim et al. 2014). Most of these varieties show hypocotyl lengths $>8.8$ $\mathrm{cm}$ and thickness $>1.8 \mathrm{~cm}$.

\section{Sprout harvesting time}

Harvesting time of the sprouts may vary depending on the factors such as germination rate and water temperature during imbibition and incubation. Also, seeds from old lots tend to show poor germination and poor growth, and may take more time to reach desired hypocotyl lengths. However, under most conditions, sprouts can be ready for harvest after 5-7 days after the start of germination. Delaying harvest may have negative impacts on sprout quality, often due to the undesired growth of lateral roots and leaves (Liu 1999; Silva et al. 2013).

\section{Chemical treatment effects on soybean sprouts}

Soybean sprouts may have a number of problems such as poor growth, low quality, excessive lateral root growth, and seedling rot, negatively affecting total yield and market value of sprouts. To control these factors, chemical compounds like hormones were tested for their effect on sprout quality and yield. Lee and Chung (1982) observed that soybean sprouts, treated with growth regulators like indole-3-acetic acid (IAA) and benzyladenopurine (BA) had relatively shorter roots than the controls, but fresh weight and diameter of the sprouts increased. In addition, substantial increases in crude protein, vitamin $\mathrm{C}$ and fat content of the sprouts were observed. Kang et al. (2004) reported increases in the hypocotyl to root length ratio, when soybean sprouts were treated with different BA concentrations. Inhibition of lateral roots in soybean sprouts treated with BA were observed by Kang et al. (1989). These results showed that treating soybean sprouts with growth regulators, IAA and BA produced sprouts with short root length, a desirable character favored in sprout production. Significant increases in useful sprout components like yield, weight, hypocotyl thickness, vitamin C 


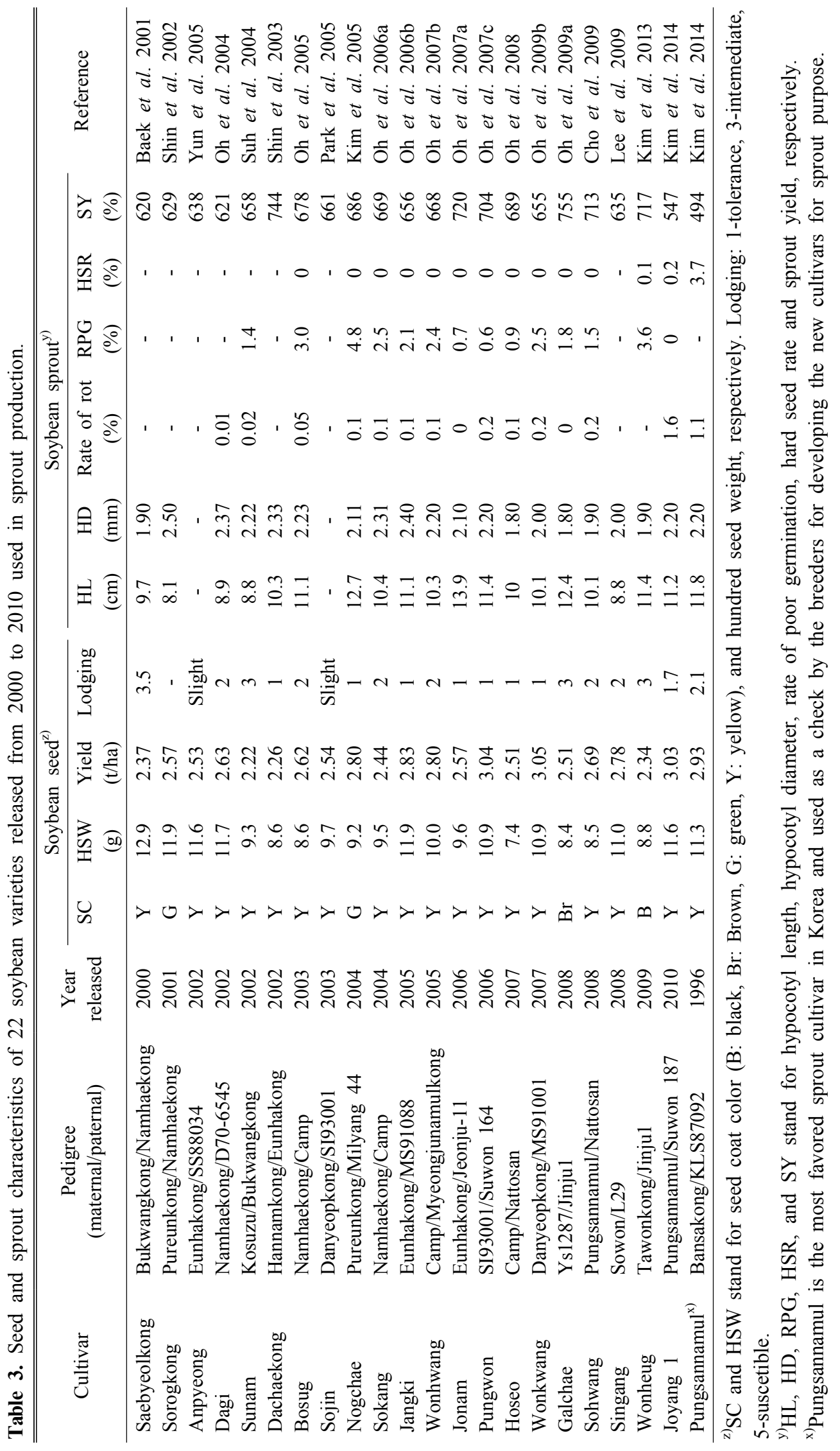


and isoflavone contents were observed, when 6-day-old soybean sprouts were treated with carbonated water $(\mathrm{pH}$ 4.5) (Hwang 2012). Similar results were obtained when soybean sprouts were treated with chitosan, a linear polysaccharide and a natural antimicrobial compound (Lee et al. 1999b), and phosphate buffer (Choi et al. 2000a). Utilization of natural chemicals that act as plant growth regulators can help to enhance the efficiency of the soybean sprout production.

\section{BREEDING SOYBEAN VARIETIES FOR SPROUT USAGE}

Soybean is called the king among legume crops in terms of importance, agronomic traits, chemical composition, seed color, seed size and other characters (Liu 1999). Korea has a long history of inclusion of soybean sprouts in their food culture (https://en.wikipedia.org/wiki/Kongnamul). Before the start of modern breeding, several local varieties with small seed size and yellow colored seed coats were utilized for sprout production (Kwon et al. 1981; Lee et al. 1992; Jeong et al. 2007).

Breeding for sprout soybeans, breeders used several criteria such as, having a 100 -seed weight of around $10 \mathrm{~g}$, seed with good germination (more than $90 \%$ germination after harvesting) and seed vigor, bright hypocotyl color, yellow cotyledons, increased hypocotyl length, and sprout yield (sprout yield $\%=$ weight of sprout $\times 100 /$ initial seed weight). In 1970, the two cultivars, Danyeobkong (Essex) and Hill were introduced from the US to Korea for cultivation of soybean sprouts (Lee et al. 2015). The variety Eunhakong (Shin et al. 1988), first bred in Korea for soybean sprouts was released in 1986. Before the 1990s, only three varieties, Pangsakong (Hong et al. 1985), Eunhakong (Shin et al. 1988) and Namhaekong (Shin et al. 1989) were bred for sprout purposes (Lee et al. 2015). During the late 1990s soybean breeders expanded their breeding efforts to improve soybeans for sprout usage because of increased consumption and demand for sprouts as a vegetable. After the 1990 s, about 41 varieties were developed for sprout production in Korea. Out of the 41 varieties, 16 varieties had small seeds and with 100 -seed weight ranging from 7.4-9.7 g. The other 25 varieties had small to medium sized seeds and their 100 -seed weight ranged from 10.0-20.1 g. Selection of small seeded soybean for sprout production is highly essential (Kim et al. 2000). Other traits considered important in sprout breeding programs have been high nutritive value and resistance to lodging, shattering and diseases. Most commercial soybean varieties have yellow colored seed coats, which is highly preferred for sprout production and consumption. Some of the varieties with excellent traits for soybean sprout usage recently developed in Korea are given in Table 3. Eighteen the 21 varieties listed in the Table 3 are yellow seeded. Further, 11 out of 21 varieties had $<10 \mathrm{~g}$ of 100 -seed weight and 10 out of 21 varieties had $<13 \mathrm{~g}$ per 100 -seed weight. These data show a preference by breeders for traits like small seed, and yellow seed coats while developing cultivars for sprout usage. Varieties like Nogchae (Kim et al. 2005), which is short in height with fewer branches, are preferred for dense field cultivation. Many of these varieties have resistance to some bacterial and viral diseases. Nineteen out of 21 soybean varieties are resistant to the soybean mosaic virus. The varieties Joyang1 (Kim et al. 2014) and Wonheug (Kim et al. 2013), in addition to soybean mosaic virus also show resistance to the bacterial pustule disease.

\section{GENETIC VARIATION IN THE SOYBEAN GERMPLASM}

Wild (Glycine soja) and cultivated (Glycine max) soybeans exhibits great genetic diversity and show high phenotypic variation for several traits (Lee et al. 2007b). Korean soybean germplasm, especially the landraces show relatively high genetic variation (Cho et al. 2008). This diverse genetic resource may have beneficial alleles, which can be transferred to elite soybean cultivars to develop varieties for sprout production. Soybean seeds have been categorized on the basis of different characters like adaptation, variation in seed coat color, hilum color, leaf shape, flower color, maturity, and seed composition (Hong et al. 1988; Song et al. 1991). Cho et al. (2008) examined 2,765 Korean soybean landraces and categorized them in 
different groups based on usage, maturity group, and adaptation. Of these, a set of 80 accessions were evaluated for genetic variation for agronomic and sprout traits (Kwon et al. 1981; Lee et al. 1992; Jeong et al. 2007). Kwon et al. (1981) evaluated 164 native sprout soybean lines from the Korean germplasm bank with small seed size $(<15$ $\mathrm{g} / 100$-seeds) and they showed genetic variation for hypocotyl length, germination percentage and sprout yield. Jeong et al. (2007) evaluated 783 soybean lines, which also included landraces distributed by the National Agrobiodiversity Center of Korea (http://genebank.rda.go.kr/), for sprout characteristics and reported substantial variation for sprout yield (range, 483\%-550\%; mean, 516\%), whole sprout length (range, 15.3-16.6 cm; mean, $15.92 \mathrm{~cm}$ ), root length (range, 5.4-6.4 cm; mean, $5.9 \mathrm{~cm}$ ) and hypocotyl length (range, 9.6-10.5 cm; mean, $10.08 \mathrm{~cm}$ ). They also observed that the range of 100-seed weight was 8.1-15.1 g with an average $11.6 \mathrm{~g}$, and the distribution of seed coat color was $28 \%$ yellow, $11 \%$ green, $19 \%$ black, and $38 \%$ for mixed. Based on these characteristics, they selected 18 superior lines as breeding material for the development of high-quality soybean varieties for sprouts.

Phenotypic evaluation and selection of the sprout related traits, particularly at the germination stage may not be easy, as these are highly affected by the other factors mentioned above (Kim et al. 2000). Sprout related traits are quantitative in nature (Kim et al. 2000) and DNA-based markers or quantitative trait loci (QTL) controlling these traits can be identified and utilized in marker assisted selection for improvement of varieties for sprout usage. Although several QTL mapping studies for yield and other agronomical important traits have been reported in soybean, there are a few studies of mapping QTLs for sprout-related traits. Lee et al. (1999a) detected several restriction fragment length polymorphism markers associated with the sprout-related traits such as hypocotyl length and sprout yield in an F2 derived population derived from a cross of Pureunkong (Pureun) $\times$ Jinpumkong 2 (Jinpum 2). In another study, Lee et al. (2001) assessed variation for the sprout-related traits in $100 \mathrm{~F} 2$ lines from the cross of Pureun $\times$ Jinpum 2 and identified 10 markers associated with sprout yield, 7 markers linked to QTLs for seed weight and 5 markers linked to QTLs for hypocotyl length. Apart from these reports, no considerable efforts have been made to identify QTLs controlling sprout-related traits. Little mapping information is available for sprout traits, QTL information for related traits like seed size, seed weight and seed coat color (www.soybase.org), would be useful to identify closely linked markers applicable in marker-assisted selection for superior sprout soybean cultivars.

\section{CONCLUSION AND FUTURE PROSPECTS}

Soybean sprouts are an important traditional vegetable food in Korea. Soybean sprouts have high nutritional value and are easy to produce. Optimum consumption of sprouts can provide the recommended dietary allowance of protein, vitamins, amino acids and isoflavones. Due to these benefits, there is steady demand for soybean sprouts in the market. Thus, it is essential to improve soybean cultivars that can produce high quality sprouts. The information presented in this review about the nutrients, health benefits and genetic variation for sprout characteristics will be helpful for breeders and farmers, especially in variety selection and improvement. Since soybeans with small seed are highly preferred in sprouting, the molecular markers/QTLs closely linked to the seed size can be utilized in the selection process. At present, favorable traits like long hypocotyls with short roots and high soybean sprout yield are being produced through different chemical applications in most small companies. Hence, to reduce chemical use, studies revealing the mode of gene action for hypocotyl elongation, hypocotyl thickness, and delayed lateral root formation need to be determined. Evaluation of soybean germplasm for the target traits and identification of QTLs/genes controlling sprout-related traits could help in the genetic improvement of varieties for sprout purposes. In addition, utilization of wild relatives, with favorable alleles for these traits would allow for inter-specific crosses between cultivated and wild soybeans to identify and explore novel alleles useful in improving soybeans for sprout production. 


\section{ACKNOWLEDGEMENTS}

This work was carried out with the support of "Cooperative Research Program for Agriculture Science \& Technology Development” (Project No. PJ01118303), Rural Development Administration, Republic of Korea.

\section{REFERENCES}

Allred CD, Allred KF, Ju YH, Goeppinger TS, Doerge DR, Helferich WG. 2004. Soy processing influences growth of estrogen-dependent breast cancer tumors. Carcinogenesis 25: 1649-1657.

Anderson JJB, Ganer SC. 1997. The effects of phytoestrogens on bone. Nutr. Res. 17: 1617-1632.

Asensi-Fabado MA, Munné-Bosch S. 2010. Vitamins in plants: Occurrence, biosynthesis and antioxidant function. Trends Plant Sci. 15: 582-592.

Baek IY, Kang ST, Shin DC, Choung MG, Han WY, Song $\mathrm{SB}$, et al. 2001. A new soybean variety suitable for sprout "Saebyeolkong" with small seed size and disease resistance. Korean J. Breed. Sci. 33: 236-237.

Bau HM, Villaume C, Nicolas JP, Méjean L. 1997. Effect of germination on chemical composition, biochemical constituents and anti-nutritional factors of soybean (Glycine max) seeds. J. Sci. Food Agric. 73: 1-9.

Beeskow HC. 1944. Bean sprouts, their preparation and properties. Michigan State College, East Lansing. Tech. Bulletin No. 184: 3-31.

Byun SM, Huh NE, Lee CY. 1977. Asparagine biosynthesis in soybean sprout. J. Korean Agri. Chem. Soc. 20: 33-42.

Chi HY, Roh JS, Kim JT, Lee SJ, Kim MJ, Hahn SJ, et al. 2005. Light quality on nutritional composition and isoflavones content in soybean sprouts. Korean J. Crop Sci. 50: 415-418.

Cho GT, Lee J, Moon JK, Yoon MS, Baek HJ, Kang JH, et al. 2008. Genetic diversity and population structure of Korean soybean landrace [Glycine $\max (\mathrm{L}$.$) Merr.]. J.$ Crop Sci. Biotech. 11: 83-90.

Cho SK, Oh YJ, Kim KH, Kim YJ, Kim TS, Kim JG, et al. 2009. A new soybean cultivar "Sohwang" for sprout with disease resistance, small seed size and high sprout yielding. Korean J. Breed. Sci. 41: 640-644.

Choi HD, Kim SS, Hong HD, Lee JY. 2000b. Comparison of physicochemical and sensory characteristics of soybean sprouts from different cultivars. J. Korean Soc. Agric. Chem. Biotechnol. 43: 207-212.

Choi HD, Kim SS, Kim KT, Lee JY, Park WM. 2000a. Effect of presoaking treatments on growth and rot of soybean sprouts. Korean J. Food Sci. Technol. 32: 584-589.

Collins JL, Sanders GG. 1976. Changes in trypsin inhibitory activity in some soybean varieties during maturation and germination. J. Food Sci. 41: 168-172.

Dhakal KH, Jeong YS, Lee JD, Baek IY, Ha TJ, Hwang YH. 2009. Fatty acid composition in each structural part of soybean seed and sprout. J. Crop Sci. Biotech. 12: 97-101.

Dhakal KH, Jung KH, Chae JH, Shannon JG, Lee JD. 2014. Variation of unsaturated fatty acids in soybean sprout of high oleic acid accessions. Food Chem. 164: 70-73.

Dixon RA, Sumner LW. 2003. Legume natural products: Understanding and manipulating complex pathways for human and animal health. Plant Physiol. 131: 878-885.

Doblado R, Frías J, Vidal-Valverde C. 2007. Changes in vitamin $\mathrm{C}$ content and antioxidant capacity of raw and germinated cowpea (Vigna sinensis var. carilla) seeds induced by high pressure treatment. Food Chem. 101: 918-923.

Eldridge AC, Black LT, Wolf WJ. 1979. Carbohydrate composition of soybean flours, protein concentrates, and isolates. J. Agric. Food Chem. 27: 799-802.

Fenwick DE, Oakenfull D. 1983. Saponin content of food plants and some prepared foods. J. Sci. Food Agric. 34: 186-191.

Friedman M, Brandon DL. 2001. Nutritional and health benefits of soy proteins. J. Agric. Food Chem. 49: 10691086.

Hartwig EE, Kuo TM, Kenty MM. 1997. Seed protein and its relationship to soluble sugars in soybean. Crop Sci. 37: 770-773.

Hochstein P, Atallah AS. 1988. The nature of oxidants and antioxidant systems in the inhibition of mutation and cancer. Mutat. Res. 202: 363-375.

Hoeck JA, Fehr WR, Murphy PA, Welke GA. 2000. Influence of genotype and environment on isoflavones contents of soybean. Crop Sci. 40: 48-51.

Hong EH, Kim SD, Hwang YH, Lee HS. 1988. Breeding strategy for 21st century: Leguminous grain crops. Korean J. Breed. Sci. 20: 13-18.

Hong EH, Kim SD, Hwang YH, Lee YH, Moon YH, Ham YS, 
et al. 1985. A new high yielding and disease resistant sprouting soybean variety, Pangsakong. RDA. J. Agri. Sci. 27: 183-185.

Hwang TY. 2012. Quality characteristics of soybean sprouts cultivated with carbonated water. Korean J. Food Preserv. 19: 428-432.

Hymowitz T, Collins FI. 1974. Variability of sugar content in seed of Glycine $\max (\mathrm{L}$.) Merrill and G. soja Sieb and Zucc. Agron. J. 66: 239-240.

Jang SY, Han S. 2016. Changes of soyasaponin contents in soybean sprouts. Korean J. Crop Sci. 61: 57-63.

Jeong YS, Dhakal KH, Lee JD, Hwang YH. 2007. Selection of superior lines based on the practical and useful characteristics in Korean indigenous soy sprout germplasm. Korean J. Breed. Sci. 39: 20-26.

Kang CK, Lee JM, Saka H. 1989. Effect of plant growth regulator treatments on the growth and lateral root formation in soybean sprouts, 2; Effect of plant growth regulator treatment on the ethylene evolution in soybean sprouts. Korean. J. Weed Sci. 9: 56-68.

Kang EY, Kim EH, Chung IM, Ahn JK. 2012. Variation of $\beta$-carotene concentration in soybean seed and sprout. Korean J. Crop Sci. 57: 324-330.

Kang EY, Kim SH, Kim SL, Seo SH, Kim EH, Song HK, et al. 2010. Comparison of soyasapogenol A, B concentrations in soybean seeds and sprouts. Korean J. Crop Sci. 55: $165-176$

Kang JH, Cho YJ, Jeon BS, Yoon SY, Jeon SH, Kim HK. 2004. Effect of benzyladenopurine concentration on growth and morphology of soybean sprouts and comparison with selling products. Korean J. Plant Res. 17: $94-101$

Karasulu E, Buyukhelvacigil M, Yıldız M, Ertugrul A, Buyukhelvacigil K, Ustun Z, et al. 2011. Soybean oil production process, benefits and uses in pharmaceutical dosage form. p.283-310. In: H. El-Shemy (ed.). Soybean and health. InTech, Rijeka, Croatia.

Kim HS, Lee SH, Park KY, Lee YH. 2000. Identification of quantitative trait loci associated with seed size and weight in soybean. Korean J. Crop Sci. 45: 227-231.

Kim HT, Baek IY, Han WY, Ko JM, Lee YH, Jung CS, et al. 2014. Sprout soybean cultivar "Joyang 1" tolerant to bacterial pustule. Korean J. Breed. Sci. 46: 290-294.

Kim HT, Baek IY, Oh YJ, Cho SK, Han WY, Ko JM, et al. 2013. A new soybean cultivar "Wonheug" for sprout with small seed, black seed coat and disease tolerance. Korean J. Breed. Sci. 45: 273-277.

Kim JS, Kim JG, Kim WJ. 2004. Changes in isoflavone and oligosaccharides of soybeans during germination. Korean J. Food Sci. Technol. 36: 294-298.

Kim KH. 1981. Studies on the growing characteristics of soybean sprout. Korean J. Food Sci. Technol. 13: 247-252.

Kim KH, Oh YJ, Suh SK, Park HK, Kim SD, Kim DK, et al. 2005. A new sprout soybean cultivar "Nogchae" with green seed coat and green cotyledon. Korean J. Breed. Sci. 37: 271-272.

Kim SD, Park KY, Lee YH, Yun HT, Lee SH, Kim YH, et al. 1996. A black seed coat soybean variety with small seed and lodging resistant Tawonkong. RDA. J. Crop Sci. 40: 102-106.

Kim YH, Hwang YH, Lee HS. 2003. Analysis of isoflavones for 66 varieties of sprout beans and bean sprouts. Korean J. Food Sci. Technol. 35: 568-575.

Kim YH, Kim SD, Hong EH. 1994. Characteristics of soy sprouts cultivated with soybeans for sprouts. RDA. J. Agri. Sci. 36: 107-112.

Kim YJ, Oh YJ, Cho SK, Kim JG, Park MR, Yun SJ. 2006. Variations of isoflavone contents in seeds and sprouts of sprout soybean cultivars. Korean J. Crop Sci. 51: 160-165.

Koo SC, Kim SG, Bae DW, Kim HY, Kim HT, Lee YH, et al. 2015. Biochemical and proteomic analysis of soybean sprouts at different germination temperatures. J. Korean Soc. Appl. Biol. Chem. 58: 397-407.

Kraemer K, Waelti M, de Pee S, Moench-Pfanner R, Hathcock JN, Bloem MW, et al. 2008. Are low tolerable upper intake levels for vitamin A undermining effective food fortification efforts? Nutr. Rev. 66: 517-525.

Kwon SH, Im KH, Kim JR. 1972. Studies on diversity of seed weight in Korean soybean landraces and wild soybean. Korean J. Breed. Sci. 4: 70-74.

Kwon SH, Lee YI, Kim JR. 1981. Evaluation of important sprouting characteristics of edible soybean sprout cultivars. Korean J. Breed. Sci. 13: 202-206.

Kylen AM, McCready RM. 1975. Nutrients in seeds and sprouts of alfalfa, lentils, mung beans and soybeans. J. Food Sci. 40: 1008-1009.

Lee C, Choi MS, Kim HT, Yun HT, Lee B, Chung YS, et al. 2015. Soybean importance as a crop and pedigree reconstruction of Korean varieties. Plant Breed. Biotech. 3: 
179-196.

Lee J, Hwang YS, Lee JD, Chang WS, Choung MG. 2013. Metabolic alterations of lutein, $\beta$-carotene and chlorophyll $\alpha$ during germination of two soybean sprout varieties. Food Chem. 141: 3177-3182.

Lee J, Renita M, Fioritto RJ, St Martin SK, Schwartz SJ, Vodovotz Y. 2004. Isoflavone characterization and antioxidant activity of Ohio soybeans. J. Agric. Food Chem. 52: 2647-2651.

Lee JC, Hwang YH. 1996. Variation of asparagine and aspartic acid contents in beansprout soybeans. Korean J. Crop Sci. 41: 592-599.

Lee JD, Hwang YH, Cho HY, Kim DU, Choung MG. 2002. Comparison of characteristics related with sprouts between Glycine max and G. Soja. Korean J. Crop Sci. 47: 189-195.

Lee JD, Shannon JG, Jeong YS. Lee JM, Hwang YH. 2007a. A simple method for evaluation of sprout characters in soybean. Euphytica 153: 171-180.

Lee JD, Yu JK, Hwang YH, Blake S, So YS, Lee GJ, et al. 2007b. Genetic diversity of wild soybean (Glycine soja Sieb. and Zucc.) accessions from South Korea and other countries. Crop Sci. 48: 606-616.

Lee SC, Choi GG, Chang YN, Sheo HI. 1992. Studies on the performances characteristics of collected native sprout soybean. 1; Variation of characteristics in collected native sprout soybean. Korean J. Breed. Sci. 24: 87-95.

Lee SH, Chung DH. 1982. Studies on the effects of plant growth regulator on growth and nutrition compositions in soybean sprout. J. Korean Agric. Chem. Soc. 25: 75-82.

Lee SH, Park KY, Lee HS, Boerma HR. 1999a. Identification of quantitative trait loci associated with traits of soybean for sprout. Korean J. Crop Sci. 44: 166-170.

Lee SH, Park KY, Lee HS, Park EH, Boerma HR. 2001. Genetic mapping of QTLs conditioning soybean sprout yield and quality. Theor. Appl. Genet. 103: 702-709.

Lee SJ, Ahn JK, Khanh TD, Chun SC, Kim SL, Ro HM, et al. 2007c. Comparison of isoflavone concentrations in soybean (Glycine max (L.) Merrill) sprouts grown under two different light conditions. J. Agric. Food Chem. 55: 9415-9421.

Lee SK, Moon JK, Jeong KH, Seo MJ, Kim YH, Yun HT, et al. 2009. A new variety "Singang" with resistance to soybean mosaic virus by molecular marker assisted selection. Korean J. Breed. Sci. 41: 568-573.
Lee SO, Simons AL, Murphy PA, Hendrich S. 2005. Soyasaponins lowered plasma cholesterol and increased fecal bile acids in female golden Syrian hamsters. Exp. Biol. Med. 230: 472-478.

Lee YS, Park RD, Rhee CO. 1999b. Effect of chitosan treatment on growing characteristics of soybean sprouts. Korean J. Food Sci. Technol. 31: 153-157.

Liu K. 1999. Soybeans: Chemistry, technology, and utilization. Aspen publishers, Inc., Gaithersburg, Maryland.

Messina M. 2000. Soyfoods and soybean phyto-oestrogens (isoflavones) as possible alternatives to hormone replacement therapy (HRT). Eur. J. Cancer 36 Suppl 4: S71-S72.

Messina MJ, Persky V, Setchell KD, Barnes S. 1994. Soy intake and cancer risk: A review of the in vitro and in vivo data. Nutr. Cancer 21: 113-131.

Miret JA, Munné-Bosch S. 2014. Plant amino acid-derived vitamins: Biosynthesis and function. Amino. Acids. 46: 809-824.

Mizuno T, Yamada K. 2006. Proximate composition, fatty acid composition and free amino acid composition of sprouts. J. Integr. Study Diet. Habits. 16: 369-375.

Mostafa MM, Rahma EH. 1987. Chemical and nutritional changes in soybean during germination. Food Chem. 23: 257-275.

Oh BY, Park BH, Ham KS. 2003. Changes of saponin during the cultivation of soybean sprout. Korean J. Food Sci. Technol. 35: 1039-1044.

Oh YJ, Cho SK, Kim KH, Kim YJ, Kim TS, Kim JG, et al. 2008. A new sprout soybean cultivar "Hoseo" with early maturity, small seed size and high sprout yielding. Korean J. Breed. Sci. 40: 479-483.

Oh YJ, Cho SK, Kim KH, Kim YJ, Kim TS, Kim JG, et al. 2009a. A new soybean cultivar "Galchae" for sprout with brown seed coat, small seed size and high sprout yielding. Korean J. Breed. Sci. 41: 324-327.

Oh YJ, Cho SK, Kim KH, Kim YJ, Kim TS, Kim JG, et al. 2009b. A new soybean cultivar, "Wonkwang" with sprout, high yielding, disease and lodging resistance. Korean J. Breed. Sci. 41: 158-162.

Oh YJ, Kim KH, Suh SK, Cho SK, Kim YJ, Kim SD, et al. 2007a. A new soybean cultivar, "Jonam" for sprout with early maturity, small seed size and high sprout yielding. Korean J. Breed. Sci. 39: 500-501.

Oh YJ, Kim KH, Suh SK, Kim SD, Cho SK, Park HK, et al. 2007b. A new soybean cultivar, "Wonhwang" with small 
seed size and high yielding for sprout. Korean J. Breed. Sci. 39: 82-83.

Oh YJ, Kim KH, Suh SK, Kim SD, Park HK, Kim YD, et al. 2006a. A new soybean cultivar "Sokang" for sprout with small seed size, disease resistance and high yielding. Korean J. Breed. Sci. 38: 73-74.

Oh YJ, Kim KH, Suh SK, Park HK, Lee MJ, Kim HS, et al. 2005. A new soybean cultivar for sprout with small seed size, disease resistance and high yield "Bosug". Korean J. Breed. Sci. 37: 109-110.

Oh YJ, Kim KH, Yun HT, Park KY, Suh SK, Moon JK, et al. 2007c. A new soybean cultivar, "Pungwon" for sprout with disease resistance, lodging resistance and high yielding. Korean J. Breed. Sci. 39: 502-503.

Oh YJ, Suh SK, Park HK, Kim KH, Kim HS, Kim YJ, et al. 2004. A new soybean cultivar "Dagi" suitable for sprout with high isoflavone and asparagine. Korean J. Breed. Sci. 36: 175-176.

Oh YJ, Yun HT, Park KY, Moon JK, Kim KH, Suh SK, et al. 2006b. A new soybean cultivar "Jangki” for sprout with lodging resistance and adaptability for mechanized harvest. Korean J. Breed. Sci. 38: 137-138.

Park KY, Kim SD, Ryu YH. 1994. Water uptake cotyledon damage after imbibition and hypocotyl elongation in soybean with different seed size and color. Korean J. Crop Sci. 39: 331-338.

Park KY, Yun HT, Moon JK, Lee YH, Kim SL, Seo MJ, et al. 2005. A new soybean cultivar for sprout "Sojin". Korean J. Breed. Sci. 37: 113-114.

Park MH, Kim DC, Kim BS, Nahmgoong B. 1995. Studies on pollution-free soybean sprout production and circulation market improvement. Korea Soybean Digest. 12: 51-67.

Park WM, Kim JH. 1998. Effects of watering on yield of soybean sprout. Korea Soybean Digest. 15: 46-57.

Philbrick DJ, Bureau DP, Collins FW, Holub BJ. 2003. Evidence that soyasaponin $\mathrm{Bb}$ retards disease progression in a murine model of polycystic kidney disease. Kidney Int. 63: 1230-1239.

Phommalth S, Hwang YH, Jeong YS, Kim YH. 2008. Isoflavone composition within each structural part of soybean seeds and sprouts. J. Crop Sci. Biotech. 11: 57-62.

Plaza L, de Ancos B. Cano PM. 2003. Nutritional and health-related compounds in sprouts and seeds of soybean (Glycine max), wheat (Triticum aestivum L.) and alfalfa
(Medicago sativa). Eur. Food Res. Technol. 216: 138-144.

Prakash D, Upadhyay G, Singh BN, Singh HB. 2007. Antioxidant and free radical-scavenging activities of seeds and agri-wastes of some varieties of soybean (Glycine max). Food Chem. 104: 783-790.

Price KR, Curl CL, Fenwick GR. 1986. The saponin content and sapogenol composition of the seed of 13 varieties of legume. J. Sci. Food Agric. 37: 1185-1191.

Rupasinghe HPV, Jackson CJC, Poysa V, Berardo CD, Bewley JD, Jenkinson J. 2003. Soyasapogenol A and B distribution in soybean (Glycine max L. Merr.) in relation to seed physiology, genetic variability, and growing location. J. Agric. Food Chem. 51: 5888-5894.

Seguin P, Zheng W, Smith DL, Deng W. 2004. Isoflavone content of soybean cultivars grown in eastern Canada. J. Sci. Food Agric. 84: 1327-1332.

Shi H, Nam PK, Ma Y. 2010. Comprehensive profiling of isoflavones, phytosterols, tocopherols, minerals, crude protein, lipid, and sugar during soybean (Glycine max) germination. J. Agric. Food Chem. 58: 4970-4976.

Shimoyamada M, Kudo S, Okubo K, Yamauchi F, Harada K. 1990. Distributions of saponin constituents in some varieties of soybean plant. Agric. Biol. Chem. 54: 77-81.

Shimoyamada M, Okubo K. 1991. Variation in saponin contents in germinating soybean seeds and effect of light irradiation. Agric. Biol. Chem. 55: 577-579.

Shin DC, Baek IY, Han WY, Choung MG, Oh SK, Kang ST, et al. 2003. A new soybean cultivar for sprout "Dachaekong" with small seed, early maturity, and high isoflavone content. Korean J. Breed. Sci. 35: 269-270.

Shin DC, Baek IY, Kang ST, Choung MG, Han WY, Kim SD, et al. 2002. A new soybean variety for sprout with small seed, high isoflavone content, and high yielding "Sorogkong". Korean J. Breed. Sci. 34: 134-135.

Shin DC, Kim YC, Park CK, Sung DK, Suh HS, Chung GS. 1989. A new soybean variety "Namhaekong" for bean sprouts. Res. Rept. RDA (U \& I) 31: 7-10.

Shin DC, Park CK, Cho EG, Sung DK, Chang SD, Chung GS, et al. 1988. A new high yielding and disease resistant sprouting soybean variety "Eunhakong”. Res. Rept. RDA (U \& I) 30: 17-20.

Silva HC, Braga GL, Bianchi MLP, Rossi EA. 1990. Effect of germination on oligosaccharide and reducing sugar contents of Brazilian soybean cultivars. Alim. Nutr. Sao 
Paulo. 2: 13-19.

Silva LR, Pereira MJ, Azevedo J, Goncalves RF, Valentao P, Pinho PG, et al. 2013. Glycine max (L.) Merr., Vigna radiata L. and Medicago sativa L. sprouts: A natural source of bioactive compounds. Food Res. Int. 50: 167-175.

Song HS, Lee YI, Kwon SH. 1991. Study on the agronomic traits of Korean native soybean (Glycine max). Korea Soybean Digest. 8: 1-16.

Song J, Kim SP., Hwang JJ, Son YK, Song JC, Hur HS. 2000. Physicochemical properties of soybean sprouts according to culture period. Korea Soybean Digest. 17: 84-89.

Suh SK, Kim HS, Oh YJ, Kim KH, Cho SK, Kim YJ, et al. 1996. A new soybean variety for sprout with small seed high yielding "Pungsannamulkong". Korean J. Breed. Sci. 39: 120-124.

Suh SK, Park HK, Kim KH, Oh YJ, Kim HS, Suh DY, et al. 2004. A new soybean cultivar "Sunam" suitable for sprout with early maturity and small seed. Korean J. Breed. Sci. 36: 173-174.

Tajiri T. 1980. Studies on production and keeping quality of bean sprouts, 5; Effect of conditions of storage, soaking and sprinkling of seed of beans on the sprouting and growth of the bean sprouts. J. Jpn. Soc. Food Sci. Technol. 27: 166-171.

Tanaka M, Watanabe T, Uchida T, Kanazawa T, Osanai T, Okumura K. 2006. Hypoglycemic effect of soyasaponin $\mathrm{B}$ extracted from hypocotyl on the increasing blood glucose in diabetic mice (KK-Ay/Ta). J. Jpn. Soc. Clin. Nutr. 27: 358-366.

Tsukamoto C, Shimada S, Igita K, Kudou S, Kokubun M, Okubo K, et al. 1995. Factors affecting isoflavone content in soybean seeds: Changes in isoflavones, saponins, and composition of fatty acids at different temperatures during seed development. J. Agric. Food Chem. 43: 1184-1192.

Villaluenga CM, Kuo YH, Lambein F, Frias J, Valverde CV. 2006. Kinetics of free protein amino acids, free non protein amino acids and trigonelline in soybean (Glycine max L.) and lupin (Lupinus angustifolius L.) sprouts. Eur. Food Res. Technol. 224: 177-186.
Wang Y, Chen P, Zhang B. 2014. Quantitative trait loci analysis of soluble sugar contents in soybean. Plant Breed. 133: 493-498.

Wilson RF. 2004. Seed composition. 3rd ed, p.621-795. In: H.R. Boerma, J.E. Specht (ed.). Soybeans: Improvement, production, and uses. American Society of AgronomyCrop Science Society of America-Soil Science Society of America, Madison, WI.

Xu M, Zhu M, Gu Q. 2003. Light-induced accumulation of isoflavone in soybean sprouts. Zhongguo Liangyou Xuebao. 18: 74-77.

Yang CB. 1981. Changes of nitrogen compounds and nutritional evaluation of soybean sprout. Part III. Changes of free amino acid composition. J. Korean Agri. Chem. Soc. 24: 101-104.

Yang H, Gao J, Yang A, Chen H. 2015. The ultrasoundtreated soybean seeds improve edibility and nutritional quality of soybean sprouts. Food Res. Int. 77: 704-710.

Yang MS, Kim KS, Ga HS. 1982. Effect of light on fatty acid and sterol composition in soybean seeding. J. Korean Soc. Soil Sci. Fert. 15: 251-257.

Yazdi-Samadi B, Rinne RW, Seif RD. 1977. Components of developing soybean seeds: Oil, protein, sugars, starch, organic acids, and amino acids. Agron. J. 69: 481-486.

Yoshiki Y, Kudou S, Okubo K. 1998. Relationship between chemical structures and biological activities of triterpenoid saponins from soybean. Biosci. Biotechnol. Biochem. 62: 2291-2299.

Youn JE, Kim HS, Lee KA, Kim YH. 2011. Contents of minerals and vitamins in soybean sprouts. Korean J. Crop Sci. 56: 226-232.

Yun HT, Park KY, Moon JK, Lee YH, Kim SL, Ryu YH, et al. 2005. A new lodging resistant soybean cultivar for sprout “Anpyeong”. Korean J. Breed. Sci. 37: 65-66.

Zaman C, Lin K, O’Neill W. 2010. The significance and relationships of amino acids and protein in chronic disease and general wellness. Immune System Management Inc., Ottawa, ON.

Zhu D, Hettiarachchy NS, Horax R, Chen P. 2005. Isoflavone contents in germinated soybean seeds. Plant Foods Hum. Nutr. 60: 147-151. 